\title{
Production components and yield of bushing snap bean in conventional and organic production systems ${ }^{1}$
}

\section{Componentes de produção e rendimento do feijão-vagem arbustivo em sistemas de produção convencional e orgânico}

\author{
Guilherme Renato Gomes ${ }^{2 *}$; Felipe Favoretto Furlan ${ }^{2}$; Gustavo Henrique Freiria²; \\ Leandro Simões Azeredo Gonçalves ${ }^{3}$; Lúcia Sadayo Assari Takahashi ${ }^{3}$
}

\begin{abstract}
Production systems influence crops differently, mainly in terms of yield. However, there are few studies that have evaluated different bushing snap bean genotypes in different systems. Thus, this study aimed to evaluate the production components and yield of bushing snap beans in conventional and organic production systems. The experimental design was a randomized complete block, in a factorial $6 \times$ 2 arrangement, corresponding to six genotypes and two production systems, with three replications. The genotypes Isla Manteiga Baixo ${ }^{\circledR}$, Isla Macarrão Baixo ${ }^{\circledR}$, Feltrin Vicenza Amarelo Baixo ${ }^{\circledR}$, and Feltrin Macarrão Napoli ${ }^{\circledR}$, UEL 1, and UEL 2 were submitted to the following determinations: days to flowering; plant height; medium number of pods per plant; average pod mass, length, and diameter; and yield of commercial pods. A joint analysis of variance was conducted by applying the F test, with mean comparison performed using the Tukey's test $(p<0.05)$. Anthesis of the genotypes Feltrin Vicenza Amarelo Baixo, UEL 2, Isla Macarrão Baixo, and Feltrin Macarrão Napoli is anticipated in the conventional production system. The genotype UEL 2 shows higher precocity in anthesis within the conventional system. The genotypes Isla Manteiga Baixo and UEL 1 produce more pods per plant in the conventional system. In the organic system, the genotype Feltrin Macarrão Napoli produces double the number of pods per plant compared with Isla Manteiga Baixo. The organic system leads to greater plant height and average mass, length, and diameter of pods in relation to the conventional system. The commercial pod yield of bushing snap bean is not altered by differences in the production system or genotype.
\end{abstract}

Key words: Phaseolus vulgaris. Determined growth. Pod productivity. Growing type.

\section{Resumo}

Os sistemas de produção influenciam as culturas de modo diferenciado, principalmente em termos de rendimento. No entanto, são poucos os estudos sobre avaliação de genótipos de feijão-vagem arbustivo em diferentes sistemas. Assim, objetivou-se avaliar os componentes de produção e o rendimento do feijão-vagem arbustivo em sistemas de produção convencional e orgânico. O delineamento experimental foi o de blocos casualizados, com três repetições. Os genótipos Isla Manteiga Baixo ${ }^{\circledR}$, Isla Macarrão Baixo $^{\circledR}$, Feltrin Vicenza Amarelo Baixo ${ }^{\circledR}$, Feltrin Macarrão Napoli ${ }^{\circledR}$, UEL 1 e UEL 2 foram submetidos as seguintes determinações: dias para florescimento, altura de planta, número médio de vagens por planta,

${ }^{1}$ Parte da Dissertação de Mestrado em Agronomia do primeiro autor, Universidade Estadual de Londrina, UEL, Londrina, PR, Brasil.

2 Discentes de Doutorado, Programa de Pós-Graduação em Agronomia, UEL, Centro de Ciências Agrárias, CCA, Londrina, PR, Brasil. E-mail: guigomes88@hotmail.com; ffavorettofurlan@gmail.com; gustavo-freiria@hotmail.com

3 Profs. Drs., Departamento de Agronomia, CCA, UEL, Londrina, PR, Brasil. E-mail: leandrosag@uel.br; luciasadayo@gmail. com

Author for correspondence 
massa, comprimento e diâmetro médio de vagem, e rendimento de vagens comerciais. A análise de variância conjunta, em esquema fatorial $6 \times 2$ (seis genótipos e dois sistemas de produção) foi conduzida aplicando-se o teste F, com médias comparadas pelo teste de Tukey $(\mathrm{p}<0,05)$. A antese dos genótipos Feltrin Vicenza Amarelo Baixo, UEL 2, Isla Macarrão Baixo e Feltrin Macarrão Napoli é antecipada no sistema convencional de produção. O genótipo UEL 2 apresenta maior precocidade na antese dentro do sistema convencional. Os genótipos Isla Manteiga Baixo e UEL 1 produzem mais vagens por planta no sistema convencional. No sistema orgânico, o genótipo Feltrin Macarrão Napoli produz o dobro de vagens por planta em relação a Isla Manteiga Baixo. O sistema orgânico proporciona maior altura de planta, e maior massa, comprimento e diâmetro médio de vagem em relação ao sistema convencional. O rendimento de vagens comerciais do feijão-vagem arbustivo não é alterado pelos sistemas de produção e pelos genótipos.

Palavras-chave: Phaseolus vulgaris. Crescimento determinado. Produtividade de vagens. Tipos de cultivo.

The snap bean (Phaseolus vulgaris L.) is a vegetable characterized by fresh pods that are relatively rich in vitamins, minerals, and antioxidants (ABU-REIDAH et al., 2013). In Brazil, the production data of this vegetable are incipient. Snap beans have social importance in the country, mainly for family farming, since approximately $60 \%$ of the national vegetable production is concentrated in small farms. In Paraná, most of the production comes from family farming, with the use of cultivars of determined or undetermined growth (PARANÁ, 2013).

Cultivars of determined growth or bushing have advantages over cultivars with undetermined growth, such as not needing tutoring and a shorter cycle, which allows a greater number of harvests per year. Other advantages are that the flowering and production are concentrated in a short period of time, which facilitates management and cultural treatments, and allows crops to be gathered ina single harvest (FILGUEIRA, 2003).

Research carried out in Brazil has mostly evaluated determined snap beans in conventional production systems (PEIXOTO et al., 1997; ATHANÁZIO et al., 1998; PINTO et al., 2001; MOREIRA et al., 2009). These systems are based on the intensive use of chemical fertilizers and pesticides, which increase productivity in the short term (SOUZA, 2005). However, these systems have limitations, such as a heavy dependence on industrialized inputs, and negative impact on humans and the environment (VIDAL et al., 2007). The evaluation of snap beans in different production systems is important to compare and identify the advantages of one system in relation to another, mainly in terms of yield and quality of the final product. Because they have specific characteristics, distinct production systems influence crops differently.

Organic farming has grown in Brazil, due in particular to consumer demand for healthier foods, coupled with the growing evidence of environmental damage from conventional agriculture (VIDAL et al., 2007). This type of farming is based on the ecological stability of the environment, through practices that includethe recycling of organic matter and use of natural resources (ALTIERI; NICHOLLS, 1999). The use of family labor and the higher commercial value of organic products also contribute to the viability of the system (RESENDE et al., 2010).

Several studies have compared the performance of vegetables in conventional and organic production systems. Abreu et al. (2010), Oliveira et al. (2010), and Resende et al. (2010) observed that the production of lettuce, lettuce, and rocket and onion, respectively, was improved using the organic system. In contrast, Carvalho et al. (2013), Menezes Júnior et al. (2014), and Santos et al. (2015) observed that the conventional system was superior to the organic system regarding the increase in carrot, onion, and green corn production, 
respectively. However, Bajgai et al. (2013) reported that maize and cabbage yields were similar in both production systems.

Currently, there are no reports available comparing the performance of bushing snap beans in different production systems, regardless of the sowing season. The aim of this study was to evaluate the production and yield components of bushing snap beans in conventional and organic production systems.

Bushing snap bean genotypes were evaluated in conventional and organic production systems in the autumn harvest of 2015. Sowing was carried out on March 23 and beans were harvested on June 03.
The experiments were conducted in experimental areas of the farm school of the State University of Londrina (UEL), Paraná, in a dystroferric Red Latosol area located at coordinates $23^{\circ} 23^{\prime} \mathrm{S}$, $51^{\circ} 11^{\prime} \mathrm{W}$, and at an altitude of $566 \mathrm{~m}$. The climate of the region is of type Cfa, described as humid subtropical mesothermic, with warm summers, according to the Köppen classification. The average maximum and minimum temperatures are 27.0 and $16.0^{\circ} \mathrm{C}$, respectively, with an average annual rainfall of between 1,400 and 1,600 mm (CAVIGLIONE et al., 2000). Daily precipitation, average temperature, and average relative humidity data are shown in Figure 1.

Figure 1. Daily data for rainfall, average temperature, and average relative humidity during the experimental period in both production systems. Data were obtained from the meteorological station located at farm school of UEL.

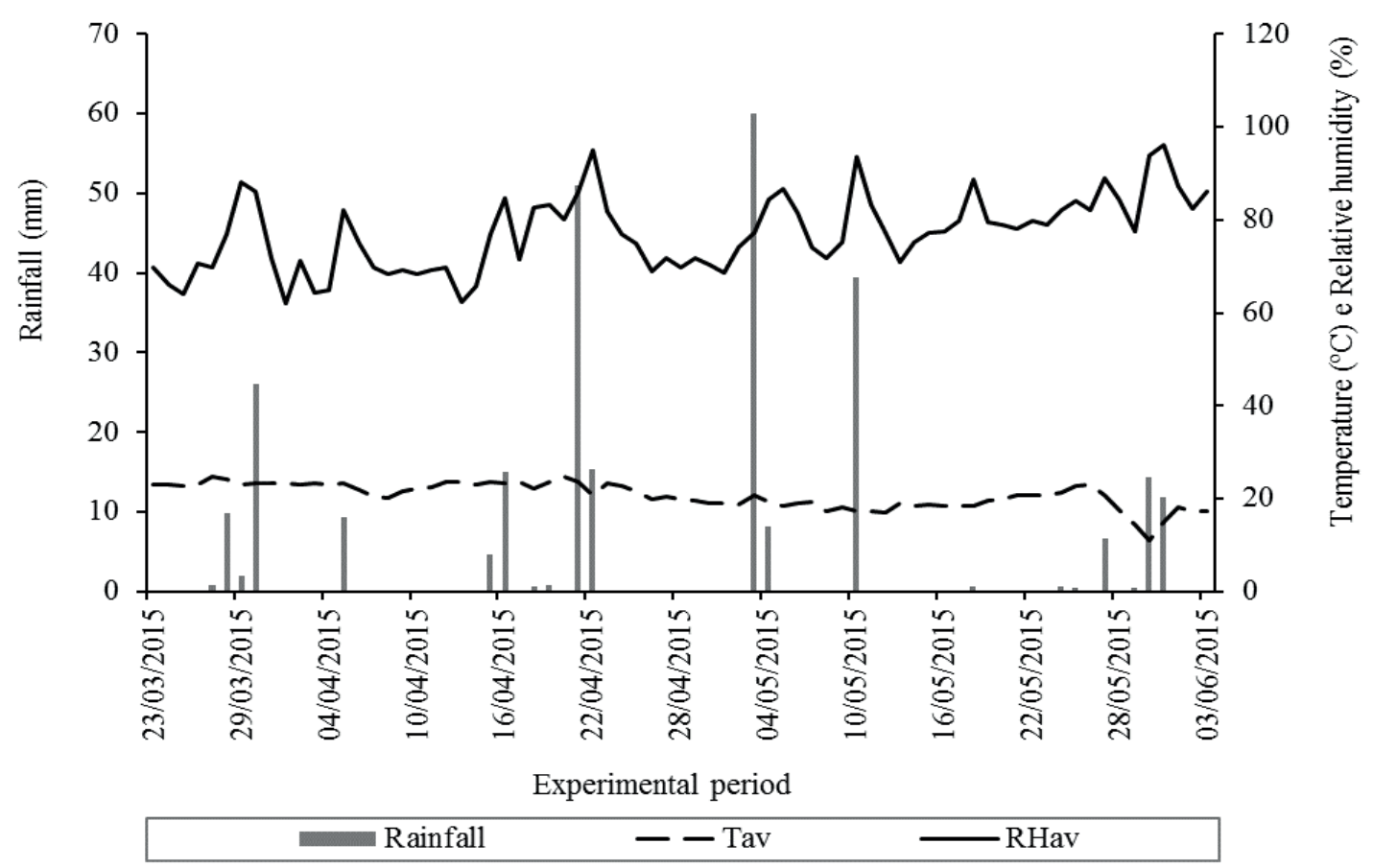

Six genotypes were evaluated, corresponding to the commercial cultivars Isla Manteiga Baixo ${ }^{\circledR}$, Isla Macarrão Baixo ${ }^{\circledR}$, Feltrin Vicenza Amarelo Baixo ${ }^{\circledR}$, and Feltrin Macarrão Napoli ${ }^{\circledR}$, as well as UEL 1 and UEL 2, which were selected in the UEL breeding program, all with pod production of the Macarrão type.

In both production systems, the experimental design was a randomized block design, with six 
treatments and three replicates. The chemical characteristics of the soil in the $0-20 \mathrm{~cm}$ layer, determined prior to the installation of the experiments, were as follows in the conventional system: $\mathrm{pH}\left(\mathrm{CaCl}_{2} 0.01 \mathrm{~mol} \mathrm{~L}^{-1}\right) 5.40 ; 32.20 \mathrm{~g} \mathrm{~kg}^{-1}$ of organic matter; $5.35 \mathrm{cmol}_{\mathrm{c}} \mathrm{dm}^{-3}$ of $\mathrm{H}^{+}+\mathrm{Al}^{3+} ; 5.50$ $\mathrm{cmol}_{\mathrm{c}} \mathrm{dm}^{-3}$ of $\mathrm{Ca}^{2+} ; 0.40 \mathrm{cmol}_{\mathrm{c}} \mathrm{dm}^{-3}$ of $\mathrm{Mg}^{2+} ; 0.33$ $\mathrm{cmol}_{\mathrm{c}} \mathrm{dm}^{-3}$ of $\mathrm{K}^{+} ; 2.18 \mathrm{mg} \mathrm{dm}^{-3}$ of $\mathrm{P}$; and $53.80 \%$ base saturation. Similarly, chemical characteristics in the organic system were as follows: $\mathrm{pH}\left(\mathrm{CaCl}_{2}\right.$ $\left.0.01 \mathrm{~mol} \mathrm{~L}^{-1}\right) 5.80 ; 41.60 \mathrm{~g} \mathrm{~kg}^{-1}$ of organic matter; $4.61 \mathrm{cmol}_{\mathrm{c}} \mathrm{dm}^{-3}$ of $\mathrm{H}^{+}+\mathrm{Al}^{3+} ; 6.70 \mathrm{cmol}_{\mathrm{c}} \mathrm{dm}^{-3}$ of $\mathrm{Ca}^{2+}$; $2.40 \mathrm{cmol}_{\mathrm{c}} \mathrm{dm}^{-3}$ of $\mathrm{Mg}^{2+} ; 0.87 \mathrm{cmol}_{\mathrm{c}} \mathrm{dm}^{-3}$ of $\mathrm{K}^{+} ; 5.78$ $\mathrm{mg} \mathrm{dm} \mathrm{m}^{-3}$ of P; and $68.38 \%$ base saturation.

On the basis of the chemical characteristics of the soils, the basic mineral fertilization in the sowing furrow and the mineral cover fertilization, carried out 15 days after the emergence of the seedlings of the different genotypes in the conventional system, were performed according to the recommendations for beans in the State of Paraná (PARRA, 2003). The basic fertilization was $20 \mathrm{~kg} \mathrm{ha}^{-1}$ of $\mathrm{N}, 60$ $\mathrm{kg} \mathrm{ha}^{-1}$ of $\mathrm{P}_{2} \mathrm{O}_{5}$, and $20 \mathrm{~kg} \mathrm{ha}^{-1}$ of $\mathrm{K}_{2} \mathrm{O}$, using the formula $10-30-10$. Urea $(45 \%$ of $\mathrm{N})$ served as a source for the cover fertilization, which was $30 \mathrm{~kg}$ $\mathrm{ha}^{-1}$ of $\mathrm{N}$. In the organic system, $3 \mathrm{~kg} \mathrm{~m}^{2}$ of compost, equivalent to $30 \mathrm{t} \mathrm{ha}^{-1}$, was incorporated, with two thirds incorporated during the preparation of the soil, 15 days before sowing, and the rest to cover, 15 days later. The compound used was produced from plant and animal material. The area devoted to organic farming had been converted more than 3 years previously, and is subjected to annual sowing and incorporation of green manure. Furthermore, during a given period of the year, the area is left fallow.

Sowing was performed manually using 10 seeds per linear meter. The experimental plots consisted of two lines with a length of $2 \mathrm{~m}$, spaced by $45 \mathrm{~cm}$. The spacing between plants was $20 \mathrm{~cm}$. After 15 days, thinning was performed, maintaining 20 plants per plot. In both production systems, two continuous lines of Isla Manteiga Baixo ${ }^{\circledR}$ were sown as a border around the experimental crops. Sprinkler irrigation was used in both production systems.

In the conventional system, phytosanitary management consisted of weed control 21 days after sowing with application of $3.0 \mathrm{~g} \mathrm{ha}^{-1}$ bentazone and $0.14 \mathrm{~g} \mathrm{ha}^{-1}$ imaxamox; control of leaf-cutting ants with application of $10 \mathrm{~g} \mathrm{~m}^{2}$ of fipronil-based bait; and control of leaf beetles [Diabrotica speciosa (Germ.)], whiteflies [Bemisia tabaci (Genn.)], and caterpillars [Spodoptera frugiperda (JE Smith)] with application of $0.5 \mathrm{~g} \mathrm{ha}^{-1}$ of imidacloprid and $0.06 \mathrm{~g} \mathrm{ha}^{-1}$ of beta-cyfluthrin, 30 and 37 days after sowing. There was no need for disease control. In the organic system, cultural control of weeds was performed by placing haulm in the sowing lines and between these lines. For pest control, a single application of $1 \%$ onion syrup (ARAÚJO, 2006) was performed before flowering.

The following evaluations were performed:(a) days for flowering (DFF): counted from sowing to the flowering stage, when $50 \%$ of the plots had at least one open flower; (b) plant height (PLHE): determined by the distance from the soil level to the apex of the main stem of 10 plants per plot, with the aid of a ruler, and expressed in centimeters; (c) average number of pods per plant (ANPP): obtained from the ratio between the number of pods and the number of plants per plot; (d) average pod mass (APM): calculated as the ratio between the pod mass and the number of pods per plot, and expressed in grams; (e) average length of pods (ALP): obtained by averaging the longitudinal length of 10 pods per plot, with the aid of a ruler, and expressed in centimeters; (f) average pod diameter (APD): determined from the average diameter in the median portion of 10 pods per plot, with the aid of a caliper, and expressed in centimeters; and $(\mathrm{g})$ commercial pod yield (CPY): determined by weighing the pods in each plot, and transforming and expressing the data in $\mathrm{tha}^{-1}$. Pods of more than 10 centimeters were used as commercials. 
Individual variance analysis for each experiment was performed and, after verifying the magnitudes of the average residual squares, a joint variance analysis was performed in a $6 \times 2$ factorial scheme (six genotypes and two production systems). Subsequently, the averages were compared using the Tukey's test at 5\% significance.

For average pod mass, length, and diameter, significant effects of genotype and production system were observed. For plant height, only the production system was significant. The interaction between genotype and production system was significant for the following variables: days for flowering and average number of pods per plant. Isolated factors, and their interactions, were not significant for pod yield. In this study, the coefficients of variation ranged between $1.81 \%$ and $25.25 \%$ (Table 1). These values are in agreement with those reported by Vidal et al. (2007), Moreira et al. (2009), and Ramírez et al. (2012), and indicate good experimental accuracy.

In the conventional system, the earliest genotypes were UEL 2, Isla Macarrão Baixo, and Feltrin Macarrão Napoli, with a period of 34, 35.33, and 35.66 days, respectively, before the beginning of the anthesis. In the organic system, Isla Manteiga Baixo, UEL 2, Isla Macarrão Baixo, UEL 1, and Feltrin Macarrão Napoli were the earliest. In general, in the organic system the genotypes had delayed flowering, which started on the 38th day and extend until the 40th day, except for UEL 1, for which a higher average flowering was observed in the conventional system, and for Isla Manteiga Baixo, for which no statistical difference was observed when comparing the systems (Table 1). Vidal et al. (2007) reported that the beginning of flowering in bushing snap beans under organic farming, in the autumn-winter, was between 46 and 47 days after sowing.

Variation in the flowering pattern between genotypes is due to genetic traits. Between production systems, it is possible that the availability of a high quantity of soluble nutrients may have caused some nutritional imbalance in the plants, and consequently stress, which led to an earlier flowering of most genotypes in the conventional system (CHABOUSSOU, 1995). The highest averages of days for flowering in the organic system can be attributed to the chelating property of organic matter, which promotes a gradual release of the nutrients and makes the environment more suitable for development of the plants, with a consequent increase in the period until the beginning of the anthesis (CARVALHO et al., 2005).

The average number of pods per plant (Table 1) was not statistically different between the genotypes in the conventional system, whereas in the organic system it was only different between Feltrin Macarrão Napoli and Isla Manteiga Baixo, with averages of 14.44 and 7.74 pods per plant, respectively. In the comparison of genotypes between the production systems, there was a difference only for the Isla Manteiga Baixo and UEL 1, and the performance of the variable was higher in the conventional system. However, the general averages of the variable were similar for both production systems.

It is possible that the variation observed for the genotypes regarding the production of pods per plant, within and between the production systems, is related to their ability to absorb available nutrients. For bushing snap beans, Moreira et al. (2009) observed a lower number of pods per plant, considering the averages of this study, for the conventional system, ranging from 2.2 to 7.1 pods per plant. In contrast, Vidal et al. (2007), using the organic system during autumn-winter, reported values of between 9.5 and 14.1 for the average pods per plant, similar to those obtained in this study.

The values of plant height and average mass, length, and diameter of pods were higher in the organic system. Except for plant height, in which there was no difference between the genotypes, Isla Manteiga Baixo (5.55 g), UEL 2 (4.95 g), and Isla Macarrão Baixo (4.90 g) had the highest average 
mass per unit of pod. For the average length of the pod, Isla Manteiga Baixo $(14.46 \mathrm{~cm})$ and Isla Manteiga Baixo $(13.46 \mathrm{~cm})$ showed higher averages compared to the other genotypes. Regarding the average pod diameter, Isla Manteiga Baixo, with an average of $1.01 \mathrm{~cm}$, had the highest value for this variable among all genotypes (Table 1).

Table 1. Variance analysis and comparison of averages of days for flowering (DFF), plant height (PLHE), average number of pods per plant (ANPP), average pod mass (APM), average pod length (APL), average pod diameter (APD), and commercial pod yield (CPY) of bushing snap bean genotypes grown during autumn-winter.

\begin{tabular}{|c|c|c|c|c|c|c|c|c|c|}
\hline \multirow{2}{*}{ Genotypes } & \multicolumn{2}{|c|}{ DFF } & \multicolumn{2}{|c|}{ ANPP } & \multirow{2}{*}{$\begin{array}{l}\text { PLHE } \\
(\mathrm{cm})\end{array}$} & \multirow{2}{*}{$\begin{array}{c}\text { APM } \\
(\mathrm{g}) \\
\end{array}$} & \multirow{2}{*}{$\begin{array}{l}\text { APL } \\
(\mathrm{cm})\end{array}$} & \multirow{2}{*}{$\begin{array}{l}\text { APD } \\
(\mathrm{cm})\end{array}$} & \multirow{2}{*}{$\begin{array}{c}\text { CPY } \\
\left(\mathrm{t} \mathrm{ha}^{-1}\right)\end{array}$} \\
\hline & Conv $^{1}$ & $\mathrm{Org}^{2}$ & Conv & Org & & & & & \\
\hline $\begin{array}{l}\text { Isla Manteiga } \\
\text { Baixo }\end{array}$ & $38 \mathrm{cA}$ & $39 \mathrm{abA}$ & $14.07 \mathrm{aA}$ & $7.74 \mathrm{bB}$ & $35.66 \mathrm{a}$ & $5.55 \mathrm{a}$ & $14.46 \mathrm{a}$ & $1.01 \mathrm{a}$ & 6.42 \\
\hline $\begin{array}{l}\text { Feltrin Vicenza } \\
\text { Amarelo Baixo }\end{array}$ & $36 \mathrm{bA}$ & $41 \mathrm{bB}$ & $12.27 \mathrm{aA}$ & $13.73 \mathrm{abA}$ & $32.36 \mathrm{a}$ & $4.58 \mathrm{bc}$ & $13.37 \mathrm{~b}$ & $0.79 \mathrm{c}$ & 6.73 \\
\hline UEL 2 & $34 \mathrm{aA}$ & $39 \mathrm{aB}$ & $11.39 \mathrm{aA}$ & $10.94 \mathrm{abA}$ & $35.38 \mathrm{a}$ & $4.95 \mathrm{ab}$ & $12.97 \mathrm{~b}$ & $0.91 \mathrm{~b}$ & 6.15 \\
\hline $\begin{array}{l}\text { Isla Macarrão } \\
\text { Baixo }\end{array}$ & $35 \mathrm{abA}$ & $39 \mathrm{aB}$ & $12.92 \mathrm{aA}$ & $12.15 \mathrm{abA}$ & $33.38 \mathrm{a}$ & $4.90 \mathrm{ab}$ & $13.46 \mathrm{ab}$ & $0.89 \mathrm{~b}$ & 6.98 \\
\hline UEL 1 & $41 \mathrm{~dB}$ & $38 \mathrm{aA}$ & $16.57 \mathrm{aA}$ & $11.21 \mathrm{abB}$ & $32.35 \mathrm{a}$ & $4.74 \mathrm{~b}$ & $13.20 \mathrm{~b}$ & $0.92 \mathrm{~b}$ & 7.27 \\
\hline \multirow[t]{2}{*}{$\begin{array}{l}\text { Feltrin Macarrão } \\
\text { Napoli }\end{array}$} & $36 \mathrm{abA}$ & $38 \mathrm{aB}$ & $10.31 \mathrm{aA}$ & $14.44 \mathrm{aA}$ & $33.02 \mathrm{a}$ & $3.96 \mathrm{c}$ & $13.39 \mathrm{~b}$ & $0.70 \mathrm{~d}$ & 5.63 \\
\hline & \multicolumn{9}{|c|}{ Production systems } \\
\hline Conventional & \multicolumn{2}{|c|}{$37 \mathrm{a}$} & \multicolumn{2}{|c|}{$12.94 \mathrm{a}$} & $29.12 \mathrm{~b}$ & $4.08 \mathrm{~b}$ & $12.95 \mathrm{~b}$ & $0.83 \mathrm{~b}$ & 6.00 \\
\hline Organic & \multicolumn{2}{|c|}{$39 \mathrm{~b}$} & \multicolumn{2}{|c|}{$11.71 \mathrm{a}$} & $38.27 \mathrm{a}$ & $5.48 \mathrm{a}$ & $14.00 \mathrm{a}$ & $0.91 \mathrm{a}$ & 7.07 \\
\hline Variation sources & \multicolumn{9}{|c|}{ Mean Square (RMS) } \\
\hline $\begin{array}{l}\text { Block / Produc- } \\
\text { tion System }\end{array}$ & \multicolumn{2}{|c|}{0.52} & \multicolumn{2}{|c|}{83.06} & 1.97 & 0.70 & 1.05 & 0.00 & 33.11 \\
\hline Genotype (G) & \multicolumn{2}{|c|}{$8.51^{* *}$} & \multicolumn{2}{|c|}{$7.59^{\mathrm{ns}}$} & $13.06^{\mathrm{ns}}$ & $1.62^{* *}$ & $1.58^{* *}$ & $0.06^{* *}$ & $2.09^{\text {ns }}$ \\
\hline $\begin{array}{l}\text { Production Sys- } \\
\text { tem (PS) }\end{array}$ & \multicolumn{2}{|c|}{$49.00^{* *}$} & \multicolumn{2}{|c|}{$13.35^{\text {ns }}$} & $754.05^{* *}$ & $17.79^{* *}$ & $10.00^{* *}$ & $0.05^{* *}$ & $10.25^{\mathrm{ns}}$ \\
\hline G $\times$ PS & \multicolumn{2}{|c|}{$10.66^{* *}$} & \multicolumn{2}{|c|}{$23.96^{*}$} & $13.88^{\mathrm{ns}}$ & $0.25^{\mathrm{ns}}$ & $0.68^{\mathrm{ns}}$ & $0.00^{\text {ns }}$ & $6.70^{\mathrm{ns}}$ \\
\hline Residue & \multicolumn{2}{|c|}{0.46} & \multicolumn{2}{|c|}{6.51} & 16.70 & 0.15 & 0.35 & 0.00 & 2.72 \\
\hline $\mathrm{CV}^{3}(\%)$ & \multicolumn{2}{|c|}{1.81} & \multicolumn{2}{|c|}{20.73} & 12.13 & 8.14 & 4.41 & 3.73 & 25.25 \\
\hline
\end{tabular}

${ }^{1}$ Conventional, ${ }^{2}$ Organic.Averages followed by the same capital letter in a row, and lower-case letter in a column, do not differ according to the Tukey test at $5 \%$. *Significant at $5 \%$, ** Significant at $1 \%$, ${ }^{\text {ns }}$ Not significant.

${ }^{3}$ Coefficient of variation.

The average pod mass values are lower than those obtained by Vidal et al. (2007) in organic farming. However, it should be emphasized that the environment and genotypes evaluated by these authors were not the same as those evaluated in the present study, and the differences in these values are certainly related to the association between genetic and environmental effects, which influences the time required for the genotypes to reach the harvest point. Regardless of the production system, the average pod length and diameter values are within the limits reported by Moreira et al. (2009) in conventional farming, which were between 10.8 and $17.1 \mathrm{~cm}$ for length, and 0.72 and $1.63 \mathrm{~cm}$ for 
diameter. In organic farming, no information on the performance of the variables was found.

Analysis of the production components between the production systems allows the establishment of an inverse relationship between the variables. In the conventional system, the average number of pods per plant was higher, whereas the height and average pod mass, length, and diameter were lower. In the organic system, the average number of pods per plant was lower, whereas height and pod mass, length, and diameter were higher.

In both systems, a change in the source/sink ratio is suggested. In the conventional system, since the plants prioritized the formation of pods, they reduced the distribution of photoassimilates for their growth and for the already formed pods, with a consequent reduction of their height and development of their pods. These results are in agreement with Andriolo and Falcão (2000), who observed that in watermelon the competition of sinks for nutrients interfered with the production and translocation of photoassimilates and, consequently, reduced plant growth. In the organic system, the plants used their reserves to grow and to feed their pods, which resulted in greater mass, length, and diameter of the pods. In this case, the formation of new pods was reduced. This adjustment between supply and demand of photoassimilates in bushing snap beans has been reported by Binnie and Clifford (1999). Pereira et al. (2003), working with bushing snap bean, also observed a compensatory effect in the average mass in an area with fewer pods per square meter.

Changes in the rate of absorption of nutrients may have changed the source-sink relationship. In the conventional system, high uptake at the beginning of the cycle, due to a rapid release of nutrients from mineral fertilization, and subsequent reduction of its availability, caused a nutritional disturbance in the plants (CARVALHO et al., 2005), which, with the aim of ensuring their propagation, increased the formation of pods. In the organic system, the source-sink relationship was altered by the gradual availability of nutrients of the organic compound throughout the plant cycle. The higher amount of organic matter in the soil contributed to this gradual availability of nutrients in this system. Therefore, with a more balanced absorption, the plants prioritized the development of the already established pods to the detriment of new pod formation.

Regarding the yield of commercial pods, the absence of significance for isolated factors, and their interaction, shows that the performance of the variable was similar in both production systems, for all genotypes, which demonstrates the productive viability of the organic system. However, studies are required to demonstrate the economic viability of the organic system, and thus establish whether it can be a realistic alternative for bushing snap bean production.

On the basis of the results obtained, it can be concluded that anthesis of the genotypes Feltrin Vicenza Amarelo Baixo, UEL 2, Isla Macarrão Baixo, and Feltrin Macarrão Napoli is anticipated in the conventional production system. The UEL 2 genotype shows higher precocity in anthesis within the conventional system.

The genotypes Isla Manteiga Baixo and UEL 1 produce more pods per plant in the conventional system.

In the organic system, the genotype Feltrin Macarrão Napoli produces twice as many pods per plant compared with Isla Manteiga Baixo.

The organic system allows for higher plant height, and higher average pod mass, length, and diameter compared with the conventional system.

The yield of commercial pods of bushing snap beans is not affected by the production systems or the genotypes. 


\section{Acknowledgments}

We thank the Coordination for the Improvement of Higher Education Personnel (CAPES) for granting a master's degree scholarship to the first author.

\section{References}

ABREU, I. M. O.; JUNQUEIRA, A. M. R.; PEIXOTO, J. R.; OLIVEIRA, S. A. Qualidade microbiológica e produtividade de alface sob adubação química e orgânica. Ciência e Tecnologia de Alimentos, Campinas, v. 30, p. 108-118, 2010. Suplemento 1.

ABU-REIDAH， I. M.; ARRÁEZ-ROMÁN， D.; LOZANO-SÁNCHEZ, J.; SEGURA-CARRETERO, A.; FERNÁNDEZ-GUTIÉRREZ, A. Phytochemical characterization of green beans (Phaseolus vulgaris L.) by using high-performance liquid chromatography coupled with time-of-flight mass spectrometry. Phytochemical Analysis, Medford, v. 24, n. 2, p. 105-116, 2013.

ALTIERI, M.; NICHOLLS, C. I. Ecologically based pest management: a key pathway to achieving agroecosystem health. In: NICHOLLS, C. I.; GARCIA, M. A.; ALTIERI, M. Curso de agroecologia: workshop sobre agroecologia e desenvolvimento sustentável. Campinas: UNICAMP, v. 2, n. 6. p. 120-124, 1999.

ANDRIOLO, J. L.; FALCÃO, L. L. Efeito da poda de folhas sobre a acumulação de matéria seca e sua repartição para os frutos do tomateiro cultivado em ambiente protegido. Revista Brasileira de Agrometeorologia, Santa Maria, v. 8, n. 1, p. 75-83, 2000.

ARAÚJO, F. F. de. Horta orgânica, implantação e manejo. Presidente Prudente: UNOESTE, 2006. 84 p.

ATHANÁZIO, J. C.; TAKAHASHI, L. S. A.; ENDO, R. M.; SILVA, G. L. UEL-2: cultivar de feijão-de-vagem tipo manteiga de crescimento determinado. Horticultura Brasileira, Brasília, v. 16, n. 1, p. 91, 1998.

BAJGAI, Y.; KRISTIANSEN, P.; HULUGALLE, N.; MC HENRY, M. Comparison of organic and conventional managements on yields, nutrients and weeds in a corncabbage rotation. Renewable Agriculture and Food Systems, Cambridge, v. 30, n. 2, p. 132-142, 2013.

BINNIE, R. C.; CLIFFORD, P. E. Sink characteristics of reproductive organs of dwarf bean in relation to likelihood of abscission. Crop Science, Madison, v. 39, n. 4, p. 1077-1082, 1999.

CARVALHO, A. D. F. de; RESENDE, F. V.; PINHEIRO, J. B.; PEREIRA, R. B.; SILVA, G. O. Avaliação de genótipos de cenoura em sistemas convencional e orgânico de produção nas condições edafoclimáticas do Distrito Federal. Brasília: Embrapa Hortaliças, 2013. 17 p. (Boletim de Pesquisa e Desenvolvimento, 94).

CARVALHO, A. M.; JUNQUEIRA, A. M. R.; VIEIRA, J. V.; REIS, A.; SILVA, J. B. C. Produtividade, florescimento prematuro e queima-das-folhas em cenoura cultivada em sistema orgânico e convencional. Horticultura Brasileira, Brasília, v. 23, n. 2, p. 250-254, 2005.

CAVIGLIONE, J. H.; KIHIL, L. R. B.; CARAMORI, P. H.; OlIVEIRA, D. Cartas climáticas do Paraná. Londrina: Instituto Agronômico do Paraná, 2000. CDROM. Versão 1.0.

CHABOUSSOU, F. As plantas doentes pelo uso de agrotóxicos: a teoria da trofobiose. Tradução de Maria José Guazzelli. 2. ed. Porto Alegre: L \& PM, 1995. 256 p.

FILGUEIRA, F. A. R. Novo manual de olericultura: agrotecnologia moderna na produção e comercialização de hortaliças. 3. ed. Viçosa, MG: UFV, 2003. 412 p.

MENEZES JÚNIOR, F. O. G.; GONÇALVES, P. A. S.; VIEIRA NETO, J. Produtividade da cebola em cultivo mínimo no sistema convencional e orgânico com biofertilizantes. Horticultura Brasileira, Vitória da Conquista, v. 32, n. 4, p. 475-481, 2014.

MOREIRA, R. M. P.; FERREIRA, J. M.; TAKAHASHI, L. S. A.; VASCONCELOS, M. E. C.; GEUS, L. C.; BOTTI, L. Potencial agronômico e divergência genética entre genótipos de feijão-vagem de crescimento determinado. Semina: Ciências Agrárias, Londrina, v. 25, p. 1051-1060, 2009. Suplemento 1.

OLIVEIRA, E. Q.; SOUZA R. J.; CRUZ, M. C. M.; MARQUES, V. B.; FRANÇA, A. C. Produtividade de alface e rúcula, em sistema consorciado, sob adubação orgânica e mineral. Horticultura Brasileira, Brasília, v. 28, n. 1, p. 36-40, 2010.

PARANÁ. Secretaria da Agricultura e do Abastecimento - SEAB. Departamento de Economia Rural - DERAL. Feijão-vagem. Comunicação Pessoal. 2013.

PARRA, M. S. Feijão. In: OLIVEIRA, E. L. Sugestão de adubação e calagem para culturas de interesse econômico no Estado do Paraná. Londrina: IAPAR, 2003. p. 17-18. (Circular, 128).

PEIXOTO, N.; THUNG, M. D. T.; SILVA, L. O.; FARIAS, J. G.; OLIVEIRA, E. B.; BARBEDO, A. S. C.; SANTOS, G. Avaliação de cultivares arbustivas de feijão-vagem, em diferentes ambientes do Estado de Goiás. Goiânia: EMATER, 1997. 22 p. (Boletim de Pesquisa, 1). 
PEREIRA, A. V.; OTTO, R. F.; REGHIN, M. Y. Respostas do feijão-vagem cultivado sob proteção com agrotêxtil em duas densidades de plantas. Horticultura Brasileira, Brasília, v. 21, n. 3, p. 564-569, 2003.

PINTO, C. M. F.; VIEIRA, C.; CALDAS, M. T. Idade de colheita do feijão-vagem anão cultivar Novirex. Horticultura Brasileira, Brasília, v. 19, n. 2, p. 163-167, 2001.

RAMÍREZ, N. S.; ESTRADA, J. A. E.; GONZÁLEZ, M. T. R.; MONTES, E. S. Rendimiento y calidad nutrimental de frijol ejotero em dos ambientes. Revista Fitotecnia Mexicana, México, v. 35, n. 4, p. 317-323, 2012.

RESENDE, J. T. V.; MARCHESE, A.; CAMARGO, L. K. P.; MARODIN, J. C.; CAMARGO, C. K.; MORALES, R. G. F. Produtividade e qualidade pós- colheita de cultivares de cebola em sistemas de cultivo orgânico e convencional. Bragantia, Campinas, v. 69, n. 2, p. 305-311, 2010.

SANTOS, N. C. B.; CARMO, S. A.; MATEUS, G. P.; KOMURO, L. K.; PEREIRA, L. B.; SOUZA, L. C. D. Características agronômicas e de desempenho produtivo de cultivares de milho-verde em sistema orgânico e convencional. Semina: Ciências Agrárias, Londrina, v. 36, n. 3, p. 1807-1822, 2015. Suplemento 1.

SOUZA, N. J. Desenvolvimento econômico. 5. ed. São Paulo: Atlas, 2005. 27 p.

VIDAL, V. L.; JUNQUEIRA, A. M. R.; PEIXOTO, N.; MORAES, E. A. Desempenho de feijão-vagem arbustivo, sob cultivo orgânico em duas épocas. Horticultura Brasileira, Brasília, v. 25, n. 1, p. 10-14, 2007. 
